\title{
Discourse and Syntax in Linguistic Change: Decline of Postverbal Topical Subjects in Serbo-Croat
}

\author{
Dejan Matić* \\ (Leipzig)
}

\section{Introduction}

The extensive discussion of the principles of word order change in the last decades has resulted in a number of proposals on how to deal with the mechanisms and the motivation for this kind of diachronic development (see e.g. Lightfoot 1999 for an overview). The proposed solutions range from the allegedly universal principle of harmonic branching (Vennemann 1975) and adaptation to human parsing capacities (Aitchinson 1979, Hawkins 1990, 1994) to switches from one parameter setting to another (e.g. Lightfoot 1979, Kroch 1989). What seems to be common to all the different approaches to word order change is that they take two finite states of grammar as their starting points (the initial state $\mathrm{X}$ and the final state $\mathrm{Y}$ ) and try to account for the stage between $\mathrm{X}$ and $\mathrm{Y}$ as a transitional state in which speakers can freely decide between at least two different grammatical choices, due either to the existence of more than one grammar in the internal language of the speakers (Kroch 1989, Pintzuk \& Taylor 2006), or to the optionality of derivations within one grammar (Wurff 1997).

The present paper deals with a word order change that cannot be attributed to syntactic processes and is therefore impossible to phrase in terms of competing grammatical choices. Postverbal topical subjects (PTS), i.e. subjects with topical interpretation placed to the right of the verb, have been attested throughout the history of Serbo-Croat (SC) ${ }^{1}$ and

* I would like to thank the participants and the organisers of the Workshop 'The Role of Information Structure in Language Change' at the $29^{\text {th }}$ Annual Meeting of the DGfS for their invaluable input. I am also grateful my Serbo-Croat language consultants, too numerous to be listed here. This paper is dedicated to the memory of Srdjan Rajković (19702006).

1 PTSs are more or less frequent in all Slavonic languages (cf. Bernecker 1900; see also Adamec 1966:66ff. for Russian, Jacennik \& Dryer 1992 for Polish), in all languages of the Balkans (cf. Myhill 1986 for Rumanian, Matić 2004 for Albanian and Greek), and in most 
seem to have kept the same frequency and the same range of functions till the $19^{\text {th }}$ century. Then, in the course of the $20^{\text {th }}$ century, the frequency and variability of PTSs rapidly declined, even though speakers are still ready to construe all types of clauses with PTSs attested in the sources from the $19^{\text {th }}$ century. There is no evidence, as we shall see, that the decline of PTSs includes any kind of shift of parametric settings in the syntax. The reasons are rather to be sought in the changes affecting the principles of discourse organisation, changes which, in turn, may perhaps be traced down to a number of interrelated sociolinguistic factors. The reduced use of a syntactic structure thus seems to be initiated by changes in pragmatics. Clearly, it cannot be ruled out that the decline in use with no syntactic consequences - and this is roughly the state in which modern SC is with respect to PTSs - will sooner or later result in a genuine syntactic change. The point is that the idea of a transitional stage between two finite states of grammar, $\mathrm{X}$ and $\mathrm{Y}$, in which both $\mathrm{X}$ and $\mathrm{Y}$ are represented in one way or another, does not seem to be the appropriate explanation for the development of PTSs in SC, and thus a fortiori not a universally applicable explanation of syntactic change.

A further question to be addressed in this paper is that of persistent lexical instantiations of a construction, i.e. those that display high frequency of usage while the construction itself is in the process of disappearing. In order to offer an explanation for the phenomenon of persistent collocations, I suggest introducing a process of automatisation, a kind of binding of syntactic structures to certain lexemes, into the repertoire of diachronic changes.

The paper is organised as follows: In Section 1, the defining features of postverbal topical subjects are introduced, in order to set this construction apart from other word order patterns with postverbal subjects. Section 2 provides a short description of the material basis and the methodology of the diachronic investigation on which the paper is based. Section 3 is dedicated to the comparative qualitative and quantitative analysis of the lexical, syntactic and discourse-pragmatic features of PTSs in two SC corpora - from the $19^{\text {th }}$ and the $20^{\text {th }} / 21^{\text {st }}$ centuries. A short overview of the patterns of usage of this construction that are still productive is provided in Section 4. Finally, in Section 5, a tentative explanation of the process in which the productive use of VsX construction has declined is put forward.

ancient Indo-European languages (Dressler 1969; see also Önnersfors 1997 and Hinterhölzl \& Petrova 2005 for detailed accounts of PTSs in Germanic). 


\section{Postverbal topical subjects}

\subsection{PTSs in VSX construction}

In SC, both in the $19^{\text {th }}$ century and in the modern variety, there are at least three structures in which the subject follows the finite verb. For ease of reference, I shall label them as follows (cf. Matić 2004 for a detailed synchronic account): (a) Inversion, a verb-second-like construction in which subjects appear postverbally after a fronted wh-word, relative pronoun, quote, and a fronted focus (cf. Alexiadou \& Anagnostopoulou 2001, 2007); (b) $v S$, a construction with a focused postverbal subject, and (c) $V s X$, a construction with a topical postverbal subject.

The present paper is devoted to the last of these, the VsX construction, in which postverbal subjects have an unequivocally topical interpretation. The label 'VsX' is borrowed from Jacennik \& Dryer (1992). The presence of ' $\mathrm{X}$ ' refers to the fact that in most cases, an additional element apart from the verb and the subject is present; capitalised ' $\mathrm{V}$ ' and ' $\mathrm{X}$ ', opposed to small ' $s$ ', are meant to give a rough indication of the intonational pattern characteristic of the construction, with accented verbs (+/- additional elements) and unaccented subjects. Example (1) displays the prototypical characteristics of the construction (the topical subject is italicised, stress is indicated with small capitals):

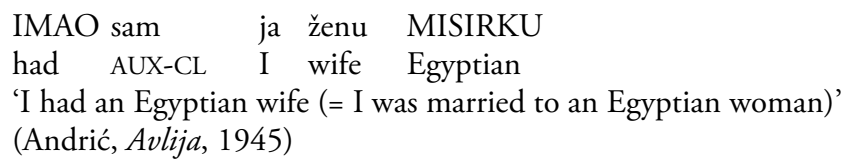

Before turning to the fate of postverbal topical subjects in VsX, I will try to demonstrate that VsX is indeed a construction in its own right, distinct from other types of structures containing postverbal subjects.

In contrast to VsX, which always occurs in matrix clauses without fronted material, Inversion is restricted to clauses in which a leftperipheral sentence slot is occupied by certain predefined types of syntactic objects (wh-words, quotes, etc.). Furthermore, the subject in Inversion may (though it need not) be accented, while the postverbal subject in VsX clauses has to be unaccented. Apart from this, there are some clear interpretational differences between the two constructions, the major one being that the subject in Inversion may, but need not be topical, whereas in VsX its topicality is a precondition for the use of the construction (see Matic 2004: 215-364). In short: Inversion is distinct from the VsX construction, i.e. the subject type used in Inversion is different from PTSs. From the practical point of view, this means that, for the purposes of this paper, the presence of a wh-word, relative pronoun, quote, etc. in the left periphery 
of a clause is a sufficient condition to leave that clause out of consideration.

The opposition between VsX and $\mathrm{vS}$ is less easy to grasp lexically. The two constructions are clearly distinct as to their interpretations, with VsX allowing only for topical, vS only for focused subjects (narrow focus on the subject or projected wide focus on the sentence). Syntactically and prosodically, there are some different statistical preferences (e.g. presence of an additional element after the subject in VsX vs. avoidance of postsubject material in vS; tendency for VsX clauses to be verb-initial vs. tendency for vS clauses to contain preverbal material, etc., cf. Matić 2004: $163 \mathrm{ff} ., 372 \mathrm{ff}$.), and at least three categorical differences:

(a) Intonation contour: In vS clauses, subjects carry the nuclear stress (a stress is indicated with small capitals):

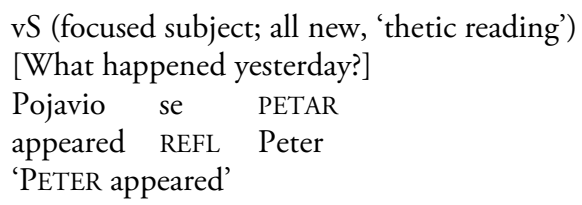

In VsX clauses with PTSs, the verb regularly gets a characteristic rise-fall intonational contour; if there is some material after the subject, it receives the nuclear stress. The subject itself can never be accented:

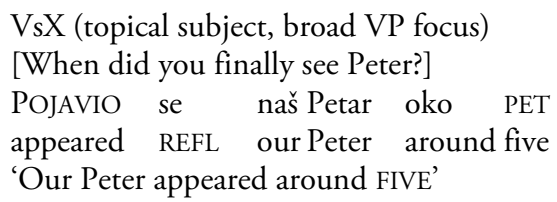

(b) Position of sentence adverbials: In vS clauses, sentence adverbials may intervene between the verb and the subject, as exemplified in (2):

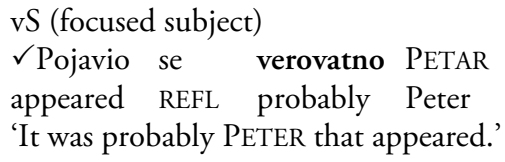

In contrast, the VsX construction does not allow for sentence adverbials to intervene between the verb and the topical subject:

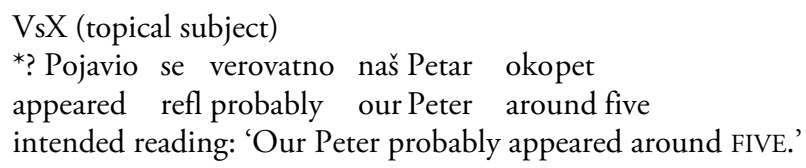

(c) Position of the subject relative to the copula/auxiliary: With focal subjects (vS construction), the subject may not intervene between the copula and the nominal predicate or the auxiliary and its complement: 
(4) vS (focused subject)

$\checkmark$ Nisu dostupni VATROGASCI

not-are available firemen

(4') *Nisu vatrogasci dostupni

Postverbal topical subjects in the VsX construction may, and indeed most often do, intervene between the copula/auxiliary and the nominal predicate/complement:

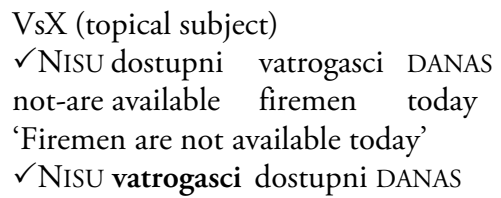

These three features - intonational differences plus syntactic discrepancies with respect to sentence adverbials and nominal predicates - may be analysed in a number of ways. For the present purposes, suffice it to conclude that $\mathrm{vS}$ and $\mathrm{VsX}$ are not only to be distinguished at the level of interpretation, but they also represent formally distinct constructions, so that their diachronic developments can be safely assumed to have run independently.

\subsection{PTSs as continuous topics}

As will become clear in the section devoted to the diachronic development of the VsX construction (Section 3.5), postverbal topical subjects fulfil a limited set of well-defined discourse functions. I will attempt to show that these functions are all derivable from one basic meaning of the immediately postverbal position in SC - that of denoting continuous topicality within a discontinuous discourse frame.

In an incremental model of communication, in which the mutual consensus on the way the world is increases step by step, with every utterance (cf. Stalnaker 1978), the status of topics with respect to this consensual knowledge may be twofold. If the speaker chooses a topic which the hearer is not entitled to expect on the basis of previous communication, the topic is discontinuous (or non-ratified, in the parlance of Lambrecht \& Michaelis 1998). If, on the other hand, the speaker assumes that the hearer may expect assertions about a certain topic, it is continuous (or ratified) topics that are used, signalling that the interlocutors have reached the mutual consensus on the further increment of knowledge before the moment of the utterance. These two kinds of choices have some grammatical relevance: discontinuous topics tend to receive secondary stress and are as a rule placed in the left periphery or extraposed, whereas continuous topics 
are typically encoded as unaccented pronouns or, if the language allows for pro-drop, they are not expressed at all (cf. Lambrecht 1994: 172ff.).

In SC, rather unspectacularly, discontinuous topical subjects are usually full NPs or accented pronouns and are found in preverbal positions (6); continuous topical subjects are usually pro-dropped (7):

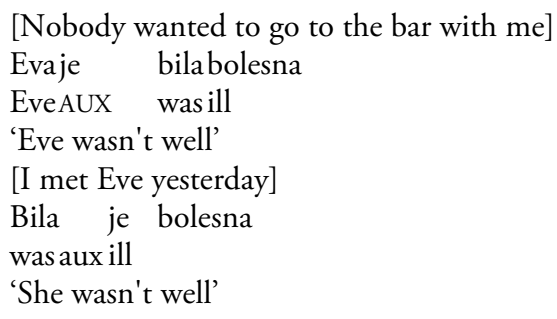

What is, then, the place of postverbal topical subjects in this system? This is where the notion of discourse frame enters the scene. The term 'discourse frame' is used here to denote space and time within one discourse universe, i.e. scene, or one discourse universe among other possible discourse universes, i.e. perspective. I would like to argue that PTSs are used in those cases in which the topic they encode is continuous, but the discourse frame changes:

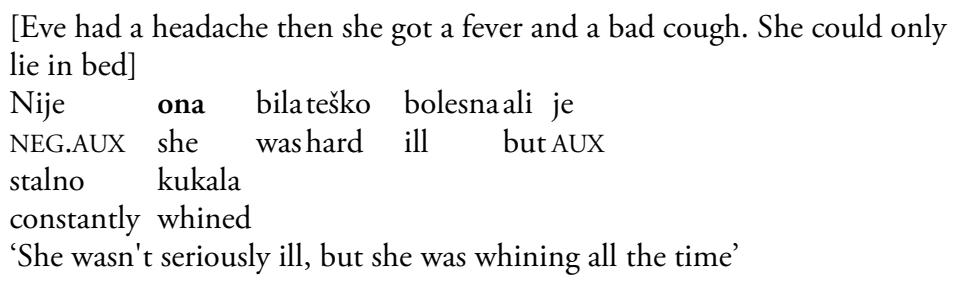

The topic of this constructed passage is continuous, in the sense that the speaker makes a series of assertions about Eve, so that the hearer is entitled to expect further information about her. The discourse frame, however, changes: in the first part (given in square brackets), the speaker assumes the perspective of an observer merely reporting what happened. In the second part (the one in which the PTS ona occurs), the perspective changes: the speaker is not an objective observer anymore, s/he is commenting upon the state of affairs s/he has just described. This combination of topic continuity and discourse frame discontinuity is unambiguously marked by the use of a PTS.

Note that (8) can also be expressed with a pro-dropped subject, or, under certain circumstances, even with a preverbal subject. This is because zero topics and preverbal topics are not sensitive to changes of scene/perspective, so that they can be used with both continuous and discontinuous discourse frames; PTSs, on the other hand, are used only with 
the latter, and only in those cases in which the speaker considers it worthwhile to mark discontinuity in the ongoing discourse. In terms of markedness, the behaviour of the three types of topical expressions can be represented as follows:

\begin{tabular}{|l||c|c|}
\hline & Topic Continuity & Discourse Frame Continuity \\
\hline \hline Preverbal Topics & - & $+/-$ \\
\hline Zero Topics & + & $+/-$ \\
\hline Postverbal Topics & + & - \\
\hline
\end{tabular}

Table 1: Meanings of topic expressions in SC

It is important to emphasise that the use of PTSs has always been optional, where 'optional' does not mean 'arbitrary', but rather 'regulated by the rules of discourse (as opposed to those of grammar)'. Taking this kind of optionality, i.e. discourse determinedness, as a starting point, I shall try to demonstrate that it was the changes in the conventions of discourse organisation that eventually led to the ousting of PTSs by preverbal and zero topics.

\section{Corpus and methods}

The present study is based on a comparison of two Serbo-Croat corpora, one comprising texts from the $19^{\text {th }}$, the other from the end of the $20^{\text {th }}$ and the beginning of the $21^{\text {st }}$ centuries. The corpora consist of approximately 10.000 clauses each $\left(19^{\text {th }}\right.$ century SC: 10.012 , modern SC: 10.005$)$. An attempt has been made to include the most relevant registers and text types in both corpora, so as to provide for comparability and as broad a coverage of genres as possible. First, two representatives of the journalistic style have been chosen for each corpus $\left(19^{\text {th }}\right.$ century SC: Letopis MS, Danica; modern SC: Vjesnik, Vesti). Second, both corpora contain parts of dramatic texts, which stand for (an imitation of) the spoken language $\left(19^{\text {th }}\right.$ century: Sterija, Rodoljupci, Pokondirena; Nušić, Sumnjivo, Narodni; modern SC: Kovačević, Špijun, Maratonci). Third, instances of predominantly narrative prose writing and of expository prose have been included in both corpora (19 ${ }^{\text {th }}$ century: Novak, Stipančići, Njegoš, Pisma; modern SC: Pavić, Predeo; Kiš, Grobnica). Finally, as representatives of oral narratives, folk stories collected in the 19th century (Pripovetke) and a $20^{\text {th }}$ century novel whose language is largely based on the techniques of oral storytelling (Andrić, Avlija) have been added.

Obviously, introspective and elicited data are not applicable in a diachronic study. However, I have used my own and the judgments of other SC speakers as a kind of additional material in order to gauge to what 
extent certain usages of VsX and PTSs are still acceptable in the modern language.

\section{PTSs in the $19^{\text {th }}$ and $20^{\text {th }}$ centuries}

\subsection{Overall frequency}

The first step in investigating the development of postverbal topical subjects in SC is to compare their absolute frequencies in the corpora. The relevant data are given in Table 2 .

\begin{tabular}{|l||c|c|}
\hline & $19^{\text {th }}$ century & $20^{\text {th }}$ century \\
\hline \hline Ratio of PTS among overt S & $9.7 \%(584)$ & $1.4 \%(79)$ \\
\hline Ratio of PTS on the whole & $5.8 \%(584)$ & $0.8 \%(79)$ \\
\hline
\end{tabular}

Table 2: Frequency of VsX clauses with PTSs in the 19th and 20th centuries

The general tendency is obvious: clauses with PTSs are roughly seven times less frequent in modern SC than in the $19^{\text {th }}$ century, both within the category of clauses with overt subjects and in the corpus as a whole. In what follows, I shall present the semantic, pragmatic and syntactic parameters along which this rapid decline in frequency took place.

\subsection{Subjects}

A very conspicuous feature that changed within the time span under consideration is the lexical nature of the subjects. Since PTSs encode continuous topics, it is only natural that the proportion of pronominal subjects in the VsX construction is somewhat higher than average. However, this proportion has dramatically changed between the $19^{\text {th }}$ and the late $20^{\text {th }} /$ early $21^{\text {st }}$ century:

\begin{tabular}{|l||c|c|}
\hline & $19^{\text {th }}$ century & $20^{\text {th }}$ century \\
\hline \hline Pronominal PST & $32.0 \%(187)$ & $64.6 \%(51)$ \\
\hline Full NP PST & $68.0 \%(397)$ & $35.4 \%(28)$ \\
\hline
\end{tabular}

Table 3: PTSs in VsX clauses in the 19th and 20th centuries

Whereas pronominal subjects make up approximately one third of all occurrences of postverbal topical subjects in the $19^{\text {th }}$ century, in modern SC they are by far the most frequent PTS type at all: almost two thirds of 
PTSs are pronominal, with only one third being expressed with full NPs. Here are two typical examples:

(9)

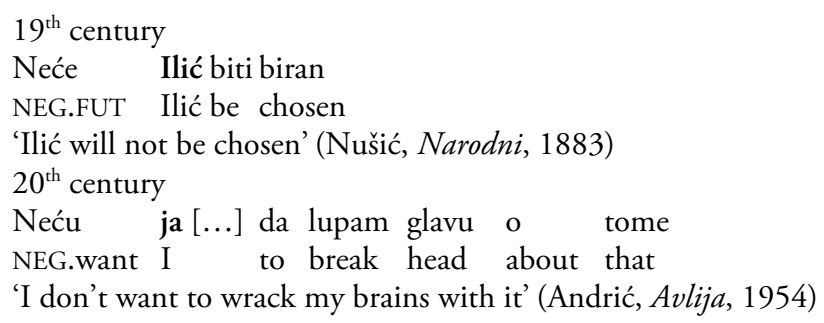

Note that (10) and (11) stand merely for typical PTSs of their respective periods: a clause like (10) is still fully grammatical and possible in modern SC, and examples like (11) are abundantly attested in the $19^{\text {th }}$ century texts. The fact is, however, that the frequency of clauses like (10), with full NP subjects, decreased by approximately fifty per cent in the course of one century.

\subsection{Verbs}

There are also interesting differences in the lexical semantics of verbs with which postverbal topical subjects appear in the VsX Construction, as Table 4 clearly shows.

\begin{tabular}{|l||c|c|c|c|c|c|}
\hline & copula & modal & cognition & emotion & existence & $\Sigma$ \\
\hline \hline $19^{\text {th }}$ & $9.9 \%$ & $7.7 \%$ & $15.1 \%$ & $13.3 \%$ & $10.5 \%$ & $56.5 \%$ \\
century & $(58)$ & $(45)$ & $(88)$ & $(78)$ & $(61)$ & $(330)$ \\
\hline $20^{\text {th }}$ & $40.5 \%$ & $15.2 \%$ & $17.7 \%$ & $6.3 \%$ & $10.1 \%$ & $89.9 \%$ \\
century & $(32)$ & $(12)$ & $(14)$ & $(5)$ & $(8)$ & $(71)$ \\
\hline
\end{tabular}

Table 4: Semantics of the predicates in VsX clauses in the 19th and 20th centuries

There are five classes of predicates prototypically occurring in VsX clauses with PTSs: the copula (biti), modal verbs (bteti [want/will], moci [can], smeti [may]), and verbs of cognition (znati [know], razumeti [understand]), emotion (uplašiti se [get scared], razljutiti se [get enraged], etc.) and existence (esp. the dynamic ones, such as pojaviti se [appear] or nestati [disappear]). The most conspicuous difference is certainly the one represented in the last column: the five prototypical verb classes cover only little more than a half of the occurrences of PTSs in the $19^{\text {th }}$ century SC, whereas in the modern language they occur in almost 90 per cent of instances. This is mostly due to a strong increase in the incidence of copular predicates (from 10 to 40 per cent) and of modal verbs (from 7 to 15 per cent); the other three classes remain at a similar level (cognition, existence) or even decrease (emotion). 
The interpretation of these facts lies at hand. The difference in the overall frequency of prototypical predicate classes can only be explained by the much wider range of predicates with which PTSs used to be combined in the $19^{\text {th }}$ century. This is an indirect sign of the greater productivity of the structure in which they occur, the VsX construction. PTSs in modern SC appear mostly with the copula, modal verbs and verbs of cognition, which account for more than 70 per cent of all occurrences. All other predicate classes are in use at best sporadically. Two typical examples are given in (11) (non-typical predicates 'grab' and 'bite') and (12) (typical predicate 'be'):

$$
\begin{aligned}
& 19^{\text {th }} \text { century } \\
& \text { Dugo se boraše Uhvati on zmiju za gušu } \\
& \text { long REFL fought caught he snake for throat } \\
& \text { Ujede ga zmija } \\
& \text { bit him snake } \\
& \text { 'They fought for a long tome. He grabbed the snake by the neck. The } \\
& \text { snake bit him and he ran away...' (Pripovetke, ca. 1820-1850) } \\
& 20^{\text {th }} \text { century } \\
& \text { Bilo je to jednog užasno studenog popodneva } \\
& \text { was AUX that one terriblycold afternoon } \\
& \text { [after a description of a funeral]'This happened on a terribly cold after } \\
& \text { noon' (Kišs, Grobinica, 1976) }
\end{aligned}
$$

A caveat similar to the one mentioned with respect to pronominal subjects is in order here. There are no grammatical, semantic, or even pragmatic restrictions on the predicates with which PTSs may be used in modern SC. The statistics presented in Table 4 and examples (11) and (12) merely show that speakers of SC have gradually stopped using PTSs with most of the predicates they were actively used with only a century ago: Even though they still can form sentences in which PTSs would be combined with any verb, they seldom do.

\subsection{Focus Structure}

The VsX construction is compatible with two kinds of focus construal: polarity (or verum) focus on the verb and wide focus on the verb and the elements to the right of the subject (see Matić 2004: 182ff. for more detail on these two types of focus construal). An example of wide focus is given in (13), in which the focus scope stretches over the predicate and the direct object to the exclusion of the topical subject (it is asserted about Ante Stipančić that he ordered a particular clothing for himself) ${ }^{2}$. Example (14)

2 Note that the wide focus construal in a VsX clause results in a discontinuous focus domain 
illustrates polarity focus on the verb (among the two possible polarities explicitly given in the question, it is the negative one that is asserted, triggering focus on the negated finite predicate):
$19^{\text {th }}$ century
[Preparations of a family for the baptism of their new born son are de scribed]
Naručio je bio Ante Stipančić za se odijelo
ordered AUX AUX A.S. for REFL clothes
senjskih plemića
Senj:adk noblemen
'Ante Stipančić had ordered for himself the uniform of the Senj nobil
ity...' (Novak, Stipančicí, 1899)
FOCUS CONSTRUAL
[Ante Stipančićc Top [had ordered the uniform] Foc
$20^{\text {th }}$ century
[A: „Can a...hen, which is worth five cervonecs, be considered equal to a polecat, which ... stinks awfully? «]
$\begin{array}{clllllll}\text { B: } N \text { Ne, } \ldots & \text { NE } & \text { MOŽE } & \text { se } & \text { ravnati } & \text { kokoška } & \text { koja } & \text { vredi } \\ \text { no } & \text { NEG } & \text { can } & \text { REFL } & \text { compare } & \text { hen } & \text { which } & \text { is.wort }\end{array}$
pet červonaca sa smrdljivim tvorom. "
fivecervonec with stinking polecat. "
"No,... a hen which is worthy five cervonecs cannot be compared to a
stinking pole cat.«'(Kis, Grobnica, 1976)
FOCUS CONSTRUAL
$[\{$ a hen can be compared to a polecat $\}$, \{polarity $=X\}]_{\text {Background }}[X=\neg]_{\text {Foc }}$

The relative frequency of these two types of focus construal has changed in the last hundred years, as the following table shows:

\begin{tabular}{|l||c|c|}
\hline & $19^{\text {th }}$ century & $20^{\text {th }}$ century \\
\hline \hline Polarity Focus Construal & $26.1 \%(152)$ & $70.9 \%(56)$ \\
\hline Wide Focus Construal & $73.9 \%(432)$ & $29.1 \%(23)$ \\
\hline
\end{tabular}

Table 6: Polarity focus and wide focus with PTSs in the 19th and the 20th centuries

What we see is almost a reversal in the frequency of the two focus types: whereas in the $19^{\text {th }}$ century wide focus was the dominant option (some three quarters of all instances), in the $20^{\text {th }}$ century SC it is the polarity focus construal that dominates, also with almost three quarters of all instances. Again, this is not a matter of grammatical or any other restrictions: both the wide and the polarity foci can still be used with PTSs, so that a clause like (14) would be fully acceptable today as it was in the $19^{\text {th }}$

in which the subject disrupts the flow of focal information (see Lambrecht 1994 and Matic 2003 for more detail on discontinuous focus domains). 
century. However, only the latter option seems to be actually employed with some regularity.

\subsection{Discourse Functions}

As already mentioned, VsX clauses with PTSs perform certain discourse functions in a number of well-defined contexts. The nature of these functions is determined by two factors: (a) by the discourse meaning of continuous topics, which are used in contexts in which the referential frame is stable, while the spatio-temporal stage or the perspective change, and (b) by the focus construal.

VsX clauses with polarity focus are employed in two basic groups of functions: first, to express certain types of illocutionary force (confirmation/denial, promise/threat, question/answer/wish, etc. - cf. (14) for the use of PTSs in answers, and (15) for a PTS clause expressing reassurance), and second, as textual cohesion devices (concession, adversativity - cf. example (16) for a VsX clause in a concessive context).

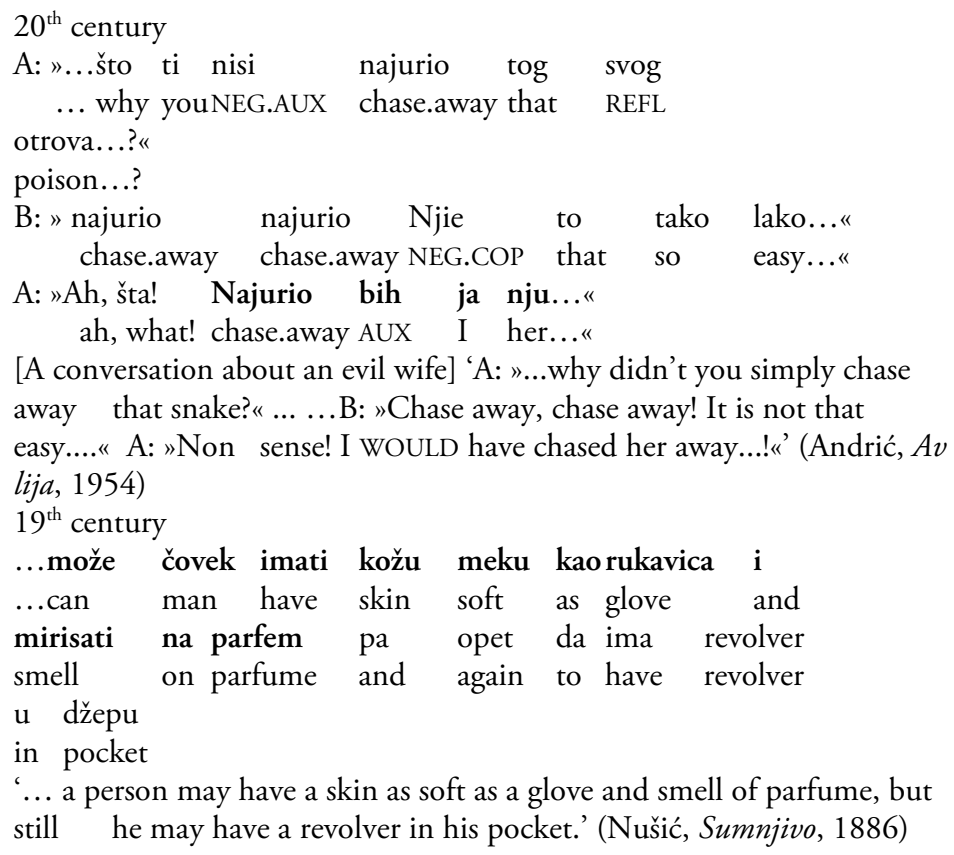

Wide focus VsX clauses are often used to mark descriptive digressions in narrative chains (cf. ex. (12) for a digressive clause containing the copula), to open or close a paragraph (ex. (17), also with the copula), or to resume an interrupted narrative thread. Furthermore, they appear in clauses that 
encode consecutive actions (ex. (11)) or events representing reactions to other events (cf. ex. (18)). ${ }^{3}$

$20^{\text {th }}$ century (paragraph closing)
Bila je to kruna svaga njegova
was AUX that crown all his
nastojanja da se.. svijetu
effort that REFL world
predočišto je jedan mali narod sposoban stvoriti
show what is one small nation capablemake

[In a funeral speech for the Croatian president Tudjman: 'Dr. Tudjman returned from Rome tired, but proud of the exhibition which was a con firmation of the Croatian identity, which is more than thousand years old.] It was the culmination of his efforts ... to show the world what a small nation is able to create...'(Vijesnik, 1999)

$19^{\text {th }}$ century (reactive event chains)

$\begin{array}{lllllll}\text { Bio je } & \text { on poša pred svjatago } & \text { Nikolaja na } \\ \text { AUX AUX } & \text { he go } & \text { before holy } & \text { N. } & \text { to } \\ \text { Stanjeviće }[\ldots] & \text { šilja } & \text { sam } & \text { ja } & \text { za } & \text { njega momke } \\ \text { S. } & \text { send AUX } & \text { I } & \text { after } & \text { him } & \text { boys } \\ \text { dva puta } & & & & & & \\ \text { twotimes } & & & & & & \end{array}$

[This is how it all happened.] 'He had gone to Stanjevići before St. Nicholas' Day [...] and I sent my boys after him two times.'(Njegoš, Pisma, 1831)

The diachronic development of discourse functions performed by PTSs is presented in Table 7 . Note that within the group of VsX clauses with wide focus, a distinction between the clauses with copular predicates and those with all other types of predicates is made, since the diachronic developments of the copular and all other VsX clauses seem to have taken a different course.

3 For reasons of space, not all of these functions can be illustrated with examples and explained in detail. For a detailed account of the situation in modern SC in comparison to Albanian and Modern Greek, readers are referred to Matić (2004: 182-204). 


\begin{tabular}{|l||c|c|}
\hline & $19^{\text {th }}$ century & $20^{\text {th }}$ century \\
\hline \hline Polarity Focus: Illocution & + & + \\
\hline Polarity Focus: Textual Cohesion & + & $-1+$ \\
\hline \hline & & + \\
\hline \hline $\begin{array}{l}\text { Wide Focus: Copular Predicates } \\
\text { digression in narration } \\
\text { paragraph boundaries }\end{array}$ & + & \\
\hline $\begin{array}{l}\text { Wide Focus: Other Predicates } \\
\text { digression in narration } \\
\text { paragraph boundaries } \\
\text { resumption of narration } \\
\text { reactive chains } \\
\text { consecutive actions }\end{array}$ & + & - \\
\hline
\end{tabular}

Table 7: Discourse functions of PTSs in the 19th and 20th centuries

Polarity focus clauses with PTSs have retained their illocutionary uses to the full extent. Their function to mark textual cohesion via adversative or concessive rhetorical relations has been practically lost: in the modern SC corpus only 3 instances have been found, which stands in sharp contrast to some fifty clauses in the $19^{\text {th }}$ century corpus. The modern language seems to opt for explicit marking via adversative, concessive, etc. particles instead.

PTS clauses with wide focus construal have survived as a productive syntactic structure only with copular predicates. If combined with the copula, PTSs are still used in digressions and on paragraph boundaries. The combinations of PTSs and other predicate classes with wide focus construal are not attested in the modern SC corpus. This means that the discourse functions this clause type used to fulfil in the $19^{\text {th }}$ century language are not a living option for the speakers of SC anymore.

Thus, at the level of attested examples, only the illocutionary function of polarity focus clauses and two minor functions of the copular wide focus clauses seem to be still productive, at least to a certain extent. However, if native speaker intuitions are taken into consideration, i.e. if we observe not only what speakers actually do, but also what they are able to do, a picture is slightly different. All but two discourse functions of PTSs are still latently possible, i.e. speakers would still be able to use VsX clauses with all kinds of predicates with both polarity and wide focus construals in almost all discourse functions attested in the $19^{\text {th }}$ century. The only exceptions are PTSs used in encoding reactive chains (19) and consecutive actions (12): VsX clauses employed in these functions are felt to be archaic and impossible in modern SC by all the native speakers I consulted. 


\subsection{Syntax: Adjacency}

In Section 1.1 we saw that sentence adverbials between the verb and the subject are ungrammatical. With other types of constituents, this restriction cannot be expressed in terms of grammaticality, but the statistical tendencies are obvious: the finite verb and the subject tend to be adjacent, with all the additional elements of the clause following the subject. This tendency, although present already in the $19^{\text {th }}$ century, seems to have become especially strong in modern SC, as the following table shows:

\begin{tabular}{|l||c|c|}
\hline & $19^{\text {th }}$ century & $20^{\text {th }}$ century \\
\hline \hline [Finite Verb] [Subject] [X] & $68.8 \%(402)$ & $94.9 \%(75)$ \\
\hline [Finite Verb] [X] [Subject] & $31.2 \%(182)$ & $5.1 \%(4)$ \\
\hline
\end{tabular}

Table 8: Relative position of $\mathrm{V}$ and $\mathrm{S}$ in the 19th and 20th centuries

Obviously, the adjacency between the finite verb and the PTS is practically a rule in today's $S C$, while it used to be merely a preferred ordering in the $19^{\text {th }}$ century. Examples (19) and (20) are typical in this respect:

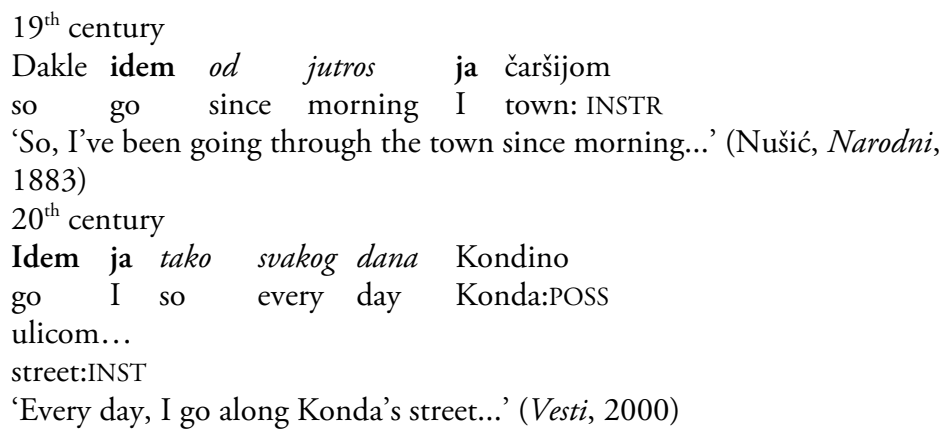

Similar to all other features described so far, this difference between the two varieties of SC is not categorical: If asked to insert an element (other than sentence adverbial) between the verb and the subject, the speakers of modern SC will do so without hesitation, but, as the statistics shows, they do not exploit this possibility in their everyday speech.

\section{What is left}

The statistical data we looked at so far reveal that the variability of the VsX construction, in which PTSs appear, has diminished in the last hundred years, which implies a gradual loss of the productivity of the construction. If we look at the most frequent patterns of usage of PTSs in modern SC, the impression of diminished productivity is confirmed. 
What is left and what accounts for some sixty to seventy per cent of all instances of PTSs in modern SC is a number of more or less petrified verb-subject collocations which regularly receive one focus construal, typical for that particular V-S combination, and are regularly used in one particular discourse function. The most frequent combinations are listed here:

$$
\begin{aligned}
& \text { Modal Verb/Verb of Cognition/Emotion + Pronominal Subject } \\
& \text { (ne) znam ja/znaš ti/zna on ... [(not) know I/know you/knows he ...] } \\
& \text { 'I (don't) know/you (don't) know /he (doesn't) know...' } \\
& \text { (ne) umem ja / umeš ti / ume on ... [(not) can I/can you/can he ...] } \\
& \text { 'I am (not) able/you are (not) able/he is (not) able...' } \\
& \text { neću ja / né́es ti / neće on ... [not.want I/not.want you/not.want he ...]' } \\
& \text { 'I don't want/you don't want/he doesn't want...' } \\
& \text { (ne) mogu ja /možeš ti / može on ... [(not) can I/can you/can he... ] } \\
& \text { 'I can('t)/you can('t)/he can('t) ...' } \\
& \text { (ne) volim ja / volis ti / voli on [(not) love I/love you/loves he...] } \\
& \text { 'I (don't) like/you (don't) like/he (doesn't) like...' }
\end{aligned}
$$

The type of verb-subject combination illustrated in (22) regularly receives polarity focus interpretation and expresses one of the illocutions typically connected with PTSs (confirmation, denial, threat, promise, etc.). It covers some 28 per cent of all instances of PTSs in modern SC.

The second frequent type of the VsX construction still very much in use - the copula with a pronominal subject - is confined to wide focus construal and appears exclusively in descriptive digressions in narration and on paragraph boundaries. It accounts for some 35 per cent of all instances of PTSs in modern SC.

$$
\begin{aligned}
& \text { Copula + Pronominal Subject } \\
& \text { bio je to / bila je to / bili su to [was.M/.F/.PL AUX that] } \\
& \text { It was (him/her/them) ..." } \\
& \text { nije to bio / nije to bila / nisu to bili [NEG.AUX that was.M/.F/.PL] } \\
& \text { 'It wasn't (him/her/them)...' } \\
& \text { bio sam ja / bio je on / bili su oni [was AUX I/he/they] } \\
& \text { 'I was/he was/they were ...' }
\end{aligned}
$$

The situation can thus be summarised as follows:

\begin{tabular}{|l||c|c|}
\hline & $\begin{array}{c}\text { Modal Verb, etc. } \\
\text { + Pronoun }\end{array}$ & $\begin{array}{c}\text { Copula } \\
\text { + Pronoun }\end{array}$ \\
\hline \hline Focus Construal & polarity focus & wide focus \\
\hline Discourse Function & illocution & $\begin{array}{c}\text { digression } \\
\text { paragraph boundaries }\end{array}$ \\
\hline Percentage & $27,8 \%$ (22 tokens) & $35,4 \%$ (28 tokens $)$ \\
\hline Percentage $(\Sigma)$ & \multicolumn{2}{|c|}{$63,2 \%(50$ tokens) } \\
\hline
\end{tabular}

Table 9: Patterns of usage of PTSs in modern SC 
The most interesting row in the table is the last one, which shows that some ten verb-subject combinations account for approximately two thirds of all occurrences of PTSs in modern SC. The productivity of the construction is thus definitively to be considered very low, since most of the instances seem to be taken from the lexicon as ready-made combinations, and are not formed by productive rules of grammar.

\section{Interpretation}

\subsection{Mixed grammars}

As indicated in the introduction to this paper, word order change has been subject to many interpretations in the last decades, the common denominator of all approaches being the concept of an internally inconsistent transitional state between two finite, internally consistent stages of grammar, the initial stage $\mathrm{X}$ and the final stage $\mathrm{Y}$. During this transitional state, the speakers freely use the features of both $\mathrm{X}$ and $\mathrm{Y}$, the usual explanation for this apparent inconsistency being the coexistence of both grammars in the internal language of the speakers. For instance, the transition of English from OV to $\mathrm{VO}$ order is believed to have included a stage in which the speakers internalised both a left-branching and a right-branching grammar (Pintzuk \& Taylor 2006). In other words, word order change is supposed to follow the scheme $\mathrm{X}>\mathrm{X}+\mathrm{Y}>\mathrm{Y}$.

Is this teleological view of syntactic change applicable to the SC data presented in the preceding sections? Let us take a closer look at how an explanation in terms of transitional states (henceforth mixed grammars approach, MGA) would work with PTSs in SC. The initial state would be a grammar in which non-focal subjects may follow the finite verb. This would be licensed only under certain discourse conditions, which could be accounted for in terms of discourse-driven syntactic features. Let us call this state VsX Grammar. In the final state, the possibility of non-focal subjects following the verb would be excluded - say, because of the change in strength or loss of the postulated features; trivially, this would be NonVsX Grammar. In this scenario, modern SC is in a transitional state, displaying features of both VsX Grammar and Non-VsX Grammar. The speakers have a choice between the two grammars and tend to employ VsX Grammar with pronominal subjects and copular predicates, as well as with polarity focus, and Non-VsX Grammar in all other cases.

The main problem with this kind of approach is the lack of categorical evidence that would support it. Apart from one discourse-related feature (see below), all differences between $19^{\text {th }}$ century and modern SC are grad- 
ual rather than discrete, which is confirmed at two levels. First, all semantic, pragmatic and syntactic features attested in the $19^{\text {th }}$ century texts are still found in modern SC texts, only that their frequency is considerably lower; second, speakers of SC are still able to produce clauses with PTSs with the $19^{\text {th }}$ century features without judging them strange or archaic. This means that PTSs are still a part of the internal language of the present-day speakers, though a part rarely made use of. Now, it could be argued that this is not an argument against MGA: the hidden productivity of PTSs may be attributed to the still-existent VsX Grammar, the scarcity of their attestation to the growing Non-VsX Grammar. This objection suffers from one major methodological flaw: it is not falsifiable (or, for that matter, verifiable). If there are no clues for the existence of different parametric settings in the grammar - and the data presented above provide us with only one syntactic difference, which has a plausible pragmatic explanation (see 5.3) - then to posit two grammatical systems would be a pure stipulation without empirical support. Furthermore, the MGA approach would be circular here: differences in frequency, lexical properties, and discourse functions are explained by a mixed syntax, and they are the only evidence for its existence at the same time. Therefore I conclude that the change observed in the behaviour of PTSs in SC in the last hundred years is not to be handled with any variety of MGA. In fact, I shall argue that it is not a grammatical change at all, i.e. that we are much better off in explaining it if we assume that no difference in syntactic parameters is involved.

\subsection{Shifts in Discourse Organisation}

In this section, I am going to provide a (rather sketchy) account of the changes in discourse organisation which seem to have been decisive in the gradual loss of PTSs. Consider first the only change between the $19^{\text {th }}$ and the $20^{\text {th }}$ centuries that seems to have led to something resembling a categorical difference: VsX clauses with PTSs cannot function as markers of resultative and consecutive events in narratives anymore, the speakers judging them at best as very old-fashioned and, if used in modern discourse, downright weird (Section 3.5). These two discourse functions are responsible for much of the lexical variability and for the frequency of VsX clauses in the $19^{\text {th }}$ century corpus: On a moderately generous interpretation of discourse functions, resultative and consecutive VsX clauses make out some 38\% of all instances of PTSs (222: 584). Since they appear in narrative texts, clauses marking resultative and consecutive events may be filled with the full gamut of predicates compatible with narrative contexts; since narrative contexts normally include more than two topical discourse 
referents, so that pronominal reference is often not sufficiently precise, the incidence of full NP subjects in these clauses is much higher than in clauses with other typical PTS functions ${ }^{4}$. Thus, the loss of these two discourse functions implied a significant decline in both the frequency and the lexical variability of clauses with PTSs. Note that no syntactic change is postulated here: the syntax of SC clauses remains the same, what changes is the principles of discourse organisation, and this, in turn, has consequences on the productivity of the construction.

The speakers of SC used to mark a series of actions as resulting from one another or as following one another with PTSs (topical discourse referents remain constant, the perspective changes). As indicated in Section 1.2 , the use of PTSs was always optional, meaning that the speaker had a choice to mark the change of the discourse frame or to leave it underspecified. In the $19^{\text {th }}$ century, the conventions of creating a narrative chain seem to have favoured the explicit marking; in the $20^{\text {th }}$ century, the only living option is to leave it unmarked. Full NP PTSs in resultative and consecutive contexts are now replaced with preverbal topical subjects, i.e. with the SV order, while the place of VsX clauses with pronominal PTSs is taken by zero subject clauses.

The loss of resultative and consecutive functions is not the whole story in the history of the decline of PTSs. Though it does account for much of the loss of productivity of the construction, some minor discourse factors seem to have played a role as well. First, wide focus VsX clauses on paragraph boundaries and in digressions in narration are used only with the copula in modern SC, while $19^{\text {th }}$ century SC made use of all predicates in this function. This seems to be due to another change in discourse organisation: explicit marking of the structure of the paragraph via PTSs is not en vogue anymore. Both the written and the spoken language (as far as can be judged by the language of the theatre plays in my corpus) in the $20^{\text {th }}$ century seem to prefer unmarked paragraph boundaries (usually with zero subjects) and insert digressions without an indication of the change of the discourse frame. My native speaker intuitions are that the use of PTSs in these contexts is felt to be somehow 'uncool' and schoolmasterly (though not so quaint and archaic as resultative and consecutive clauses), something you would write for your teacher in a prose composition course but never utter among your friends. Thus, this change in discourse habits contributed further to the decrease in frequency of PTSs. The reason for the persistence of the copula in this function will be the topic of the following section.

4 The overall percentage of full NP subjects in VsX clauses in the $19^{\text {th }}$ century is $68,0 \%$ (397), while full NP subjects in resultative and consecutive VsX clauses amount to $88,2 \%$ (191). 
Before that, another minor change needs to be briefly mentioned. Concessive and adversative rhetorical relations expressed with polarity focus VsX clauses are still, although rarely, found in texts, but the rhetoric of the written language has shifted to the marking of these relations with conjunctions and/or particles (such as iako, mada 'although' or ali 'but'), usually combined with zero subject clauses. In contrast to the $19^{\text {th }}$ century, concessive etc. clauses with PTSs are not considered very good style in the present-day written language, but seem to be at least marginally acceptable in the colloquial registers.

The common feature of all these changes seems to be the tendency to avoid explicit marking of the change of the discourse frame under referential continuity and to leave this feature underspecified. It is unclear what triggered this new preference in discourse organisation. No research whatsoever has been done on the historical pragmatics of Serbo-Croat, so that I can merely offer a couple of hypotheses that may be a part of the explanation. First, the growing influence of Western European languages, which generally leave the change of discourse frame unmarked, may have contributed to the ousting of PTSs. Second, reactive and consecutive VsX clauses are felt to be characteristic of oral narratives and have an unmistakable folklore slant. While this may have been seen as a positive connotation in the time of Romanticism, it was definitely a feature to be avoided in the era of urbanisation and conscious creation of non-rural identity, a social process which gained momentum in the Balkans only in the $20^{\text {th }}$ century. Third, the shift of regional centres: while $19^{\text {th }}$ century SC was mostly based on the central-southern speech of Herzegovina, in which VsX clauses still seem to be a productive discourse device, the linguistic centre later moved further north, to Zagreb and Belgrade. It may be the case that the shift to the north also meant a shift away from the structures which were felt to be especially characteristic of the previous linguistic centre. I am not sure that any of these sociolinguistic factors was decisive, but it is at least plausible to assume that a shift in the pragmatics of a language has its roots in changes of the communicative preferences of its speakers, which may very well be sociologically conditioned.

\subsection{Automatisation}

There is one final issue that needs to be addressed - the issue of the types of PTSs which are still relatively frequent in modern SC. As shown in Section 4, clauses containing them fall into two groups: (1) polarity focus VsX clauses with modal verbs/verbs of cognition/emotion + pronominal subjects marking different illocutions, and (2) wide focus VsX clauses with the copula + pronominal subjects denoting paragraph boundaries or di- 
gressions. Why have precisely these two types remained more or less intact, despite the general tendency in SC to avoid explicit marking of discourse frame discontinuity via PTSs? The answer to this question is rather unspectacular: token frequency.

In polarity focus clauses used to express threats, promises, agreement and disagreement, etc., the most frequent lexical items are verbs denoting modality, emotions and propositional attitudes, usually coupled with a $1^{\text {st }}$ and $2^{\text {nd }}$ person pronominal subject, since the aforementioned illocutions normally pertain to ability, obligation, emotions and opinions, and they normally involve the speech act participants. The wide focus clauses appearing in digressions and on paragraph boundaries are almost as a rule descriptive or identificational, which implies the use of the copula, and their topics are usually discourse referents mentioned in the previous clause, so that their subjects tend to be pronominal with a greater than chance frequency.

As is often the case in the course of phonological, morphological or syntactic change, this kind of frequency phenomena may have a conserving effect even in a most sweeping language change. In the case of syntactic phenomena like the one we are dealing with, this conserving effect of particularly frequent tokens consists in the method of their storage and retrieval: instead of being accessed as productive constructions via the principle of compositionality, these tokens are both stored and retrieved as quasi-lexical items (they are 'entrenched', cf. Bybee 2007: 273). This enables them to survive the modern SC drift toward full underspecification of the changes in the discourse frame and the resulting obsolescence of PTSs.

Incidentally, the semi-lexicalisation of the most frequent verb-subject combinations also accounts for the adjacency effects observed in Section 3.6. Even though various lexical items may still intervene between the verb and the PTS, in more than $90 \%$ of the cases the verb and the PTS are adjacent, whereas in the $19^{\text {th }}$ century less than $70 \%$ of the PTSs directly followed the verb. Recall that the semi-lexicalised verb-subject combinations account for some $63 \%$ of all PTSs in the $20^{\text {th }}$ century corpus. With only one exception (ex. (15)), all clauses containing these combinations display verb-subject adjacency. Direct adjacency of this kind is a typical feature of 'entrenched' phrases (cf. Bybee 2007: 274), which is only logical in view of their being stored as ready-made phrases, not generated from generalised syntactic schemas. The rise in the ratio of the clauses with adjacent verbs and subjects is thus directly attributable to the rise in the ratio of semi-lexicalised expressions, so that there is no need to resort to incipient parametric changes in order to explain this phenomenon. 
Partial lexicalisation is not the whole story, however. For three out of the eight verb-subject collocations listed in Section 4 (bio je to 'it was', nije to bio 'it wasn't', and neć ja 'I won't/don't want to'), I was not able to find one single instance of subject-verb order in the $20^{\text {th }}$ century corpus (even though the order to je bio etc. would be perfectly grammatical). This means that semi-lexicalisation affects not only the collocation itself, but also its component parts. When the speakers are confronted with a lexical choice including a particular verb and a particular subject, they tend to automatically use the verb-subject order. Note that this is a reversal of the normal derivational process out of abstract syntactic schemes. In syntactic derivations a particular structure is paired with a particular information packaging and a particular semantics; these three components together determine the lexical filling and the discourse function of the structure. In the case of the three collocations mentioned above, the process goes the other way around: a particular lexical filling triggers the use of a particular structure. I suggest to call this type of diachronic change automatisation, and to define it as a binding of lexical items to a syntactic structure, such that the use of the lexical items automatically triggers the use of the syntactic structure. Of course, automatisation is only very weak in the case of the Serbo-Croat PTSs, since the number of lexemes affected is rather low and even those few lexemes allow for other kinds of construal, but it does seem to be well under way, at least for this limited set of lexemes.

\section{Conclusion}

The evidence presented seems to suggest that it is more plausible to conceive of the decline of PTSs in SC as a consequence of the change in the principles of discourse organisation than to postulate syntactic, or parametric, or I-language change. It is possible that, if the discourse habits of the speakers of SC remain as they are now for some time, the use of postverbal topical subjects will cease to be a living option not only at the level of discourse, but also at the level of grammar, i.e. what once started as a simple shift in the organisation of discourse will turn into a new parametric setting. If this happens, $20^{\text {th }}$ century SC will turn out to be a kind of transitional stage. However, this would be a transitional stage quite different from the one conceived of as a coexistence of two opposed grammars, since it merely includes a disuse of a grammatically perfectly possible structure for reasons beyond grammar.

Of course, this in no way implies that the idea of mixed grammatical parameters is not applicable to all those cases to which it has been applied successfully. The implication is rather that the inventory of transitional 
stages should be widened to include cases in which the initial grammar is still present, but out of use for some reason. And there is one more implication: grammatical loss can have more than just one possible trigger, contrary to the popular claim, neatly exemplified in the following quote:

People might start to use some new expression because of the social demands of fashion or because of the influence of speakers from a different community, but people do not cease to say things for that sort or reason. [...] Changes involving only the loss and obsolescence of forms need to be explained as a consequence of some change in an abstract, cognitive system. (Lightfoot 2006: 29; cf. also Lightfoot 1999:106)

As I hope to have shown, people may very well stop saying things they used to say for reasons that have to do with social demands of fashion, without deep changes in an abstract, cognitive system. Some of these fashionable changes may, of course, strike roots and lead to deeper grammatical shifts.

\section{References}

\section{Primary sources}

Andrić, Avlija (1954): I. Andrić, Prokleta avlija. Sarajevo: Svjetlost, 1981.

Danica (1849): Danica ilirska 15, Zagreb, 1849.

Kiš, Grobnica (1976): D. Kiš, Grobnica za Borisa Davidoviča. Beograd: BIGZ, 1986.

Kovačević, Maratonci (1973): D. Kovačević, Maratonci trče počasni krug. In: Odabrane drame I. Beograd: Stubovi kulture, 2001.

Kovačević, Špijun (1982): D. Kovečević, Balkanski špijun. In: Odabrane drame I. Beograd: Stubovi kulture, 2001.

Letopis MS (1874): Letopis Matice srpske 116, Novi Sad, 1874.

Njegoš, Pisma (1831-2): P. Petrović Njegoš, Izabrana dela: Gorski vijenac, Luča Mikrokozma, Pisma. Beograd: Draganić, 1998.

Novak, Stipančići (1899): V. Novak: Posljednji Stipančići. Zagreb: Mosta, 1994.

Nušić, Narodni (1883): B. Nušić, Narodni poslanik. Beograd: Rad, 1998.

Nušić, Sumnjivo (1886): B. Nušić, Sumnjivo lice. Beograd: SKZ, 2003.

Pavić, Predeo (1988): M. Pavić, Predeo slikan čajem. Beograd: BIGZ, 1990.

Pripovetke (ca. 1820-1850): V. Djurić (ed.), Antologija narodnih pripovedaka. Novi Sad: Matica Srpska, 1960. 
Sterija, Pokondirena (1838): J. Sterija Popović, Pokondirena tikva. In: Dela. Beograd: Draganić, 2006.

Sterija, Rodoljupci (1856): J. Sterija Popović, Rodoljupci. In: Dela. Beograd: Draganić, 2006.

Vjesnik (1999): Vjesnik, Zagreb, 14.12.1999.

Vesti. (2000): Vesti, Frankfurt a.M., 04.03.2000.

\section{Scientific Literature}

Adamec, P. (1966): Porjadok slov v sovremennom russkom jazyke. Praha: Academia.

Aitchinson, J. (1979): The order of word order change. Transactions of the Philological Society, 42-65.

Alexiadou, A. and E. Anagnostopoulou (2001): The subject in situ generalization, and the role of Case in driving computations. Linguistic Inquiry 32, 193-231.

Alexiadou, A. and E. Anagnostopoulou (2007): The subject-in-situ hypothesis revisited. In: H.-M. Gärtner and U. Sauerland (eds.), Proceedings of the Workshop on Interfaces + Recursion = Language? Berlin and New York: Mouton de Gruyter, 31-60.

Berneker, E. (1900): Die Wortfolge in den slawischen Sprachen. Berlin: Behr.

Dressler, W. (1969): Eine textsyntaktische Regel der idg. Wortstellung. Zeitschrift für vergleichende Sprachforschung 83, 1-25.

Hawkins, J. (1990): Seeking motives for change in typological variation. In: W. Croft, K. Denning, and S. Kemmer (eds.), Studies in Typology and Diachrony: Papers Presented to J. H. Greenberg on his 75th Birthday. Amsterdam and Philadelphia: John Benjamins, 95-122.

Hawkins, J. (1994): A Performance Theory of Order and Constituency. Cambridge: Cambridge University Press.

Hinterhölzl, R. and S. Petrova (2005): Rhetorical relations and verb placement in early Germanic languages. Evidence from the Old High German Tatian translation (9th century). In: M. Stede et al. (eds.), Salience in Discourse. Multidisciplinary Approaches to Discourse. Münster: Stichting/Nodus, 71-79.

Jacennik, B. and M. Dryer (1992): Verb-subject order in Polish. In: D. L. Payne (ed.), Pragmatics of Word Order Flexibility. Amsterdam and Philadelphia: John Benjamins, 209-241.

Kroch, A. S. (1989): Reflexes of grammar in patterns of language change. Language Variation and Change 1, 199-244.

Lambrecht, K. (1994): Information Structure and Sentence Form. Cambridge: Cambridge University Press. 
Lambrecht, K. and L. Michaelis (1998): Sentence accent in information questions: Default and projection. Linguistics and Philosophy 21, 477-544.

Lightfoot, D. W. (1979): Principles of Diachronic Syntax. Cambridge: Cambridge University Press.

Lightfoot, D. W. (1999): The Development of Language: Acquisition, Change, and Evolution. Oxford: Blackwell.

Lightfoot, D. W. (2006): Cuing a new grammar. In: A. van Kemenade and B. Los (eds.), The Handbook of the History of English. Oxford: Blackwell, 24-44.

Matić, D. (2003): Topic, focus, and discourse structure: Ancient Greek word order. Studies in Language 27, 573-633.

Matić, D. (2004): Topics, Presuppositions, and Theticity. An Empirical Study of Verb-Subject Clauses in Albanian, Modern Greek, and Serbo-Croat. Ph.D. Dissertation, University of Cologne. (KUPS publication online: http://kups.ub.uni-koeln.de/frontdoor.php?source_opus=1132)

Myhill, J. (1986): The two VS constructions in Rumanian. Linguistics 24, 331 350.

Önnerfors, O. (1997): Verb-erst-Deklarativsätze. Grammatik und Pragmatik. Stockholm: Almqvist \& Wiksell.

Pintzuk, S. \& A. Taylor (2006): Loss of OV order in the history of English. In: A. van Kemenade and B. Los (eds.), The Handbook of the History of English. Oxford: Blackwell, 249-278.

Stalnaker, R. (1978): Assertion. In: P. Cole (ed.), Pragmatics. New York: AP, 315332.

Vennemann, T. (1975): An explanation of drift. In: Ch. N. Li (ed.), Word Order and Word Order Change. Austin: University of Texas Press.

Wurff, W. van der (1997): Deriving object-verb order in Late Middle English. Journal of Linguistics 33, 485-509. 
Brought to you by | MPI fuer Psycholinguistik (Max-Planck-Gesellschaft - WIB641 Authenticated | 172.16.1.226

Download Date | 5/15/12 3:06 PM 